Jurnal ABDINUS : Jurnal Pengabdian Nusantara, 3 (1), 2019, 83-92

Available online at: http://ojs.unpkediri.ac.id/index.php/PPM

DOI: $\underline{\text { https://doi.org/10.29407/ja.v3i1.13480 }}$

\title{
Sosialisasi E-Safety Parenting Sebagai Smart Solution dalam Pendampingan Penggunaan Gadget Pada Anak
}

\author{
Prita Haryani $^{1}$ \\ 1pritaharyani@akprind.ac.id \\ ${ }^{1}$ Program Studi Teknik Informatika, Fakultas Teknologi Industri \\ ${ }^{1}$ Institut Sains \& Teknologi AKPRIND Yogyakarta
}

Received: 0208 2019. Revised: 0109 2019. Accepted: 03092019

\begin{abstract}
The e-safety parenting socialization activity aims to provide knowledge about patterns of childcare in the digital era in using smartphones, especially the use of the Internet. The socialization activities were attended by 38 participants fromTrayeman village, Plered, Bantul. The method used is lecture and question and answer. Socialization material is distributed in the form of material handouts. The implementation of e-safety parenting is getting a good response. The participants were enthusiastic in listening to lectures from the speakers. This can be seen from the many questions raised related to childcare patterns in the digital age in using smartphones, especially Internet usage. After participating in this socialization, the participants of the socialization have understood the potential or risks of children using the Internet, tips on using the Internet wisely and knowing the procedures and techniques for the prevention of negative content on the Internet. Socialization participants can also practice the steps of using the Secure Parental Control App on their smartphone. It is hoped that by taking part in the socialization of e-safety parenting, they will discuss the negative impacts of using gadgets and direct the use of these gadgets for positive activities.
\end{abstract}

Keywords: Socialization, E-safety parenting, Internet, Gadget, Smartphone,

Abstrak: Kegiatan sosialisasi e-safety parenting ini bertujuan untuk memberikan pengetahuan tentang pola pengasuhan anak di era digital yaitu dalam menggunakan smartphone khususnya penggunaan Internet. Kegiatan sosialisasi diikuti oleh 38 peserta yaitu Ibu-Ibu PKK Dusun Trayeman, Plered, Bantul. Metode yang digunakan dalam penyampaian materi sosialisasi adalah metode ceramah dan tanya jawab. Materi sosialisasi dibagikan dalam bentuk handout materi. Pelaksanaan sosialisasi e-safety parenting mendapatkan respon yang baik. Peserta sosialisasi antusias dalam mendengarkan ceramah dari narasumber. Hal ini dapat dilihat dari banyaknya pertanyaan yang diajukan terkait dengan pola pengasuhan anak di era digital dalam menggunakan smartphone khususnya penggunaan Internet. Setelah mengikuti sosialisasi ini, Ibu-Ibu PKK Dusun Trayeman sebagai peserta sosialisasi sudah memahami tentang potensi atau resiko anak menggunakan Internet, tips menggunakan Internet dengan bijak serta mengetahui tata cara dan teknik untuk pencegahan konten negatif di Internet. Peserta sosialisasi juga sudah bisa mempraktikan langkah-langkah menggunakan aplikasi App Secure Parental Control pada smartphone mereka. Diharapkan dengan mengikuti sosialisasi e-safety parenting, Ibu- 
Ibu PKK Dusun Trayeman dapat mengedukasi keluarga mereka tentang dampak negatif penggunaan gadget dan mengarahkan penggunaan gadget tersebut untuk kegiatan yang positif.

Kata kunci: Sosialisasi, E- safety parenting, Internet, Gadget, Smartphone

\section{ANALISIS SITUASI}

Dari data survey APJII (Asosiasi Pengguna Jasa Internet Indonesia) tahun 2017 dapat diketahui pertumbuhan jumlah pengguna Internet di Indonesia terus meningkat (APJII, 2017). Pada tahun 2017, pertumbuhan pengguna Internet mencapai 143,26 juta jiwa. Rentang usia anak-anak sampai remaja (13-18 tahun) yang menggunakan Internet sebesar 16,68\% dalam komposisi pengguna Internet di Indonesia berdasarkan usia. Mereka menggunakan gadget sebagai perangkat yang digunakan untuk mengakses Internet. Smartphone, tablet, komputer, kamera, laptop merupakan jenis-jenis gadget yang banyak digunakan. Dengan berbagai fitur unggulan yang dimiliki, gadget tidak hanya digunakan oleh orang kantoran untuk menyelesaikan pekerjaan, hampir setiap orang sekarang menggunakan gadget baik tua, muda bahkan anak-anak. Dengan gadget, kita bisa melakukan berbagai kegiatan, dimana saja dan kapan saja.

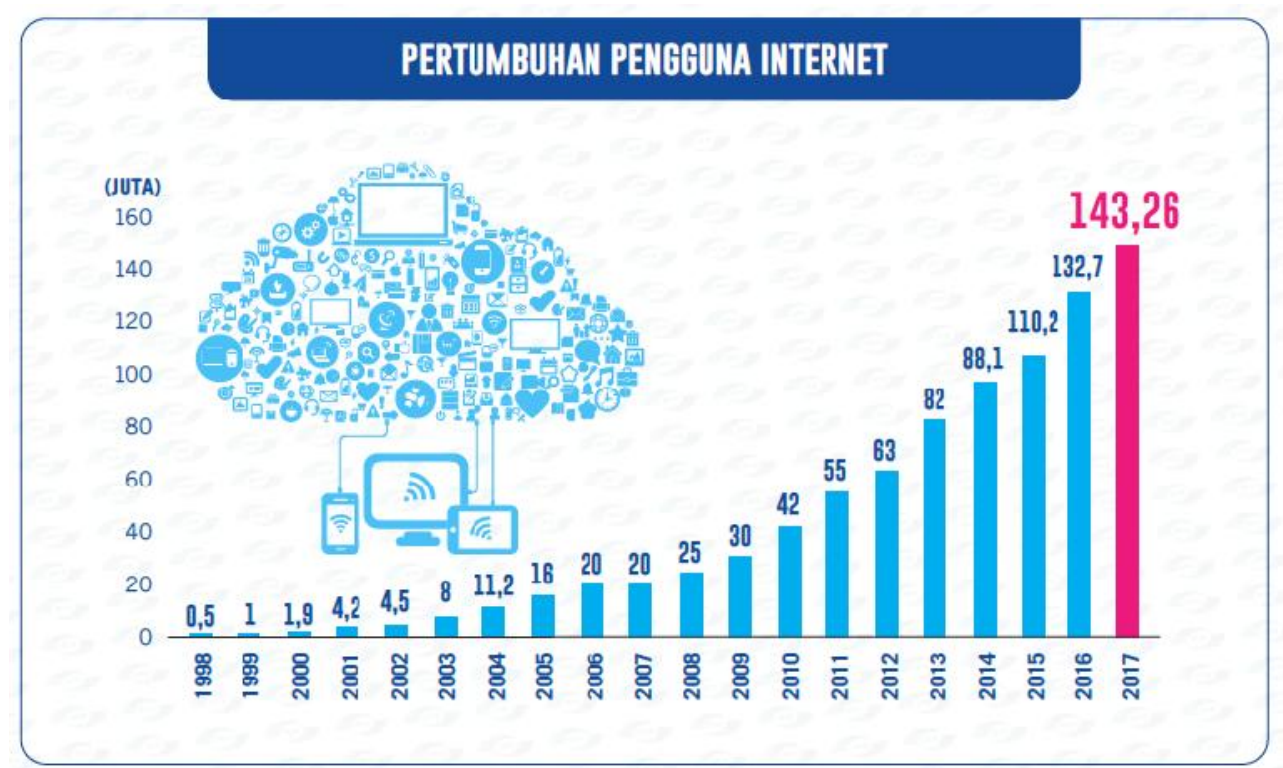

Gambar 1. Pertumbuhan Pengguna Internet di Indonesia tahun 2017 (APJII, 2017) 


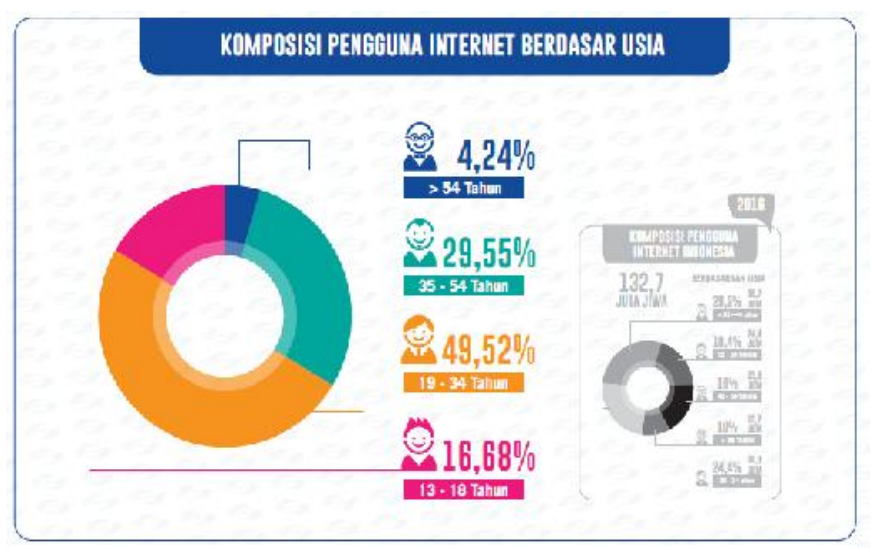

Gambar 2. Komposisi Pengguna Internet di Indonesia Berdasarkan Usia (APJII, 2017)

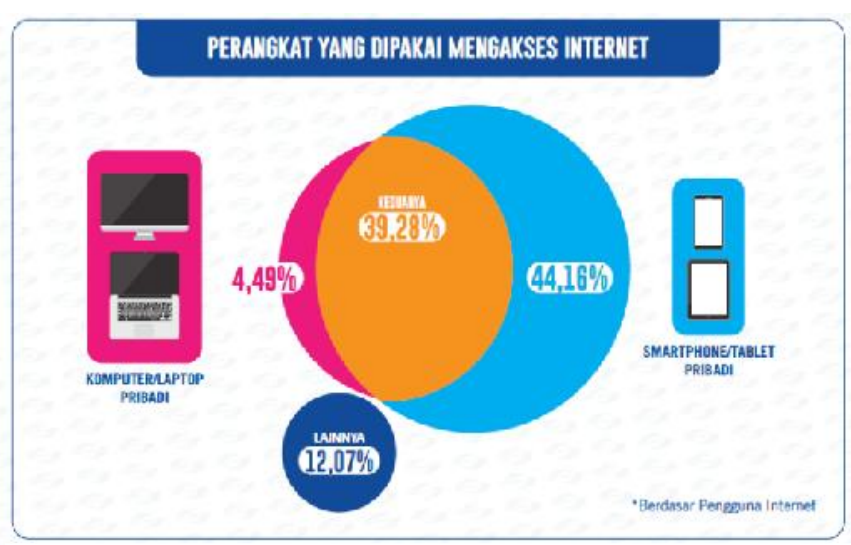

Gambar 3. Komposisi Perangkat yang Dipakai oleh Pengguna Internet (APJII, 2017)

Penggunaan gadget yang marak di kalangan anak-anak tentu menimbulkan dampak positif dan negatif. Beberapa dampak positif dari penggunaan gadget bagi anak-anak yaitu: (1) Mengembangkan daya imajinasi dan berfikir; (2) Melatih kecerdasan dengan belajar tulisan, angka dan gambar; (3) Meningkatkan rasa percaya diri ketika anak berhasil menyelesaikan suatu permainan; serta (4) Menumbuhkan rasa ingin tahu terhadap suatu hal dan kemudian mempelajarinya sehingga dapat mengembangkan kemampuan dalam membaca, matematika, dan pemecahan masalah. Sedangkan beberapa dampak negatif dari penggunaan gadget yaitu: (1) anak memiliki kecenderungan mudah menyerah; (2) anak memiliki kemampuan motorik yang kurang berkembang; (3) anak memiliki emosi yang meledak-ledak; (4) anak kurang memiliki keterampilan sosial; dan (5) ada kemungkinan anak terpapar konten berbau pornografi atau kriminalitas (Chusna, 2017).

Untuk mengurangi beberapa dampak negatif yang timbul dari penggunaan gadget, maka perlu dilakukan sosialisasi penggunaan Internet yang sehat dan aman. Sosialisasi dan pelatihan penggunaan Internet sehat juga dilakukan di desa Wojo Kabupaten Bantul. Peserta pelatihan adalah remaja masjid Aqrob. Sebelum pelaksanaan pelatihan dilakukan pembagian kuesioner untuk mengetahui sejauh mana penggunaan Internet oleh remaja di desa Wojo. Hasil kuesioner menunjukkan bahwa media Internet sudah dikenal familiar oleh remaja desa Wojo. Persoalan remaja merupakan hal yang paling banyak dibahas dalam postingan dan penggunaan media sosial oleh remaja (Sholeh \& Basuki, 2018). Sosialisasi pelatihan dan pemanfaatan Internet juga dilakukan pada siswa siswi SMK Anak Bangsa desa Bandar Siantar Kabupaten Simalungan. Kegiatan ini dilakukan untuk memberikan pengetahuan kepada para siswa dalam menggunakan Internet secara bijak. Pelatihan pemanfaatan Internet ini menggunakan 4 macam modul diktat yang masing-masing akan dijelaskan berupa 


\section{Jurnal ABDINUS : Jurnal Pengabdian Nusantara, 3 (1), 2019, 83-92 \\ Prita Haryani}

presentasi menggunakan power point (Wanto, Suhendro, \& Windarto, 2018). Sosialisasi Internet sehat dan aman juga dilakukan pada remaja di Kecamatan Cihideung. Sosialisasi Internet sehat dan aman dilakukan untuk mengurangi dampak kegiatan negatif dari kegiatan penggunaan akses Internet. Setelah dilakukan sosialisasi terlihat bahwa para remaja sangat antusias dengan materi konten situs atau media sosial yang sehat dan positif. Diharapkan dengan adanya sosialisasi Internet sehat ini, remaja di Kecamatan Cihideung bisa lebih bijak dalam memanfaatkan Internet di media sosial dan dapat memproteksi dari dampak negatif yang timbul dari penggunaan akses Internet tersebut (Fitri, Rubiani, \& Astuti, 2018).

\section{SOLUSI DAN TARGET}

Beberapa dampak negatif yang timbul dari penggunaan Internet dan gadget juga menjadi perhatian dan kekhawatiran bagi orang tua. Adanya perubahan karakter anak menjadi negatif seperti menjadi mudah menyerah, memiliki emosi yang meledak-ledak, dan kurang memiliki keterampilan sosial, serta adanya pengaruh konten negatif di Internet menjadi alasan mengapa perlu dilakukan sosialisasi e-safety parenting kepada orang tua. Orang tua perlu mengetahui potensi atau resiko anak menggunakan Internet, tips menggunakan Internet dengan bijak pada anak serta mengetahui tata cara dan teknik untuk pencegahan konten negatif di Internet, sehingga orangtua dapat mengatasi dan menangkal bahaya dari konten negatif yang ada. Oleh karena itu, pada kegiatan pengabdian masyarakat ini dilakukan sosialisasi e-safety parenting kepada orang tua khususnya Ibu-Ibu PKK Dusun Trayeman, Plered Kabupaten Bantul. Diharapkan dengan adanya sosialisasi tersebut, Ibu-Ibu PKK Dusun Trayeman dapat mengedukasi keluarga mereka tentang dampak negatif penggunaan gadget dan mengarahkan penggunaan gadget tersebut untuk kegiatan yang positif.

\section{METODE PELAKSANAAN}

Sebelum materi sosialisasi dilakukan, peserta sosialiasi mengisi kuesioener untuk mengetahui sejauh mana pemahaman peserta sosialisasi tentang dampak negatif penggunaan Internet. Metode yang digunakan dalam pelaksanaan kegiatan Pengabdian Kepada Masyarakat ini adalah metode ceramah dan tanya jawab. Materi sosialisasi dibagikan dalam bentuk handout materi. Materi sosialisasi meliputi potensi atau resiko anak menggunakan Internet, tips menggunakan Internet dengan bijak pada anak serta mengetahui tata cara dan teknik untuk pencegahan konten negatif di Internet. Pada materi akhir sosialiasi juga dipraktikan langkah-langkah menggunakan aplikasi App Secure Parental Control yang 
dipraktikan pada smartphone. Berikut adalah diagram alir pelaksanaan pengabdian masyarakat.

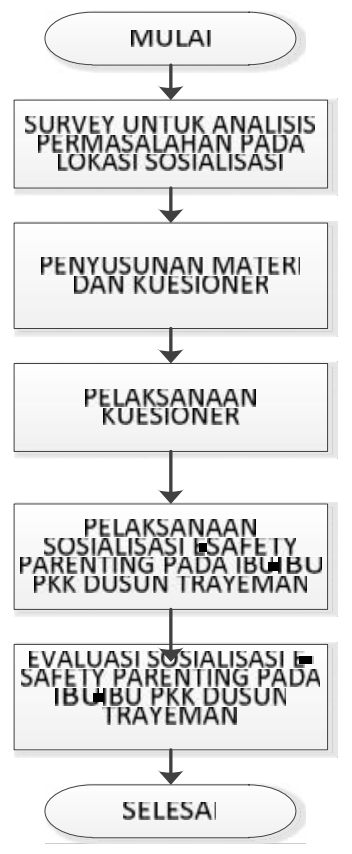

Gambar 4. Alur Pelaksanaan Pengabdian Masyarakat

\section{HASIL DAN LUARAN}

\section{Hasil Kuesioner}

Analisis hasil deskriptif kuesioner adalah sebagai berikut:

a. Situs yang sering diakses oleh anak pada saat menggunakan Internet

Dari hasil kuesioner yang telah diisi oleh peserta sosialisasi, dapat diperoleh informasi bahwa situs Internet yang sering diakses oleh anak adalah sosial media, dan game online. Situs tersebut digunakan oleh anak sebagai sarana untuk berinteraksi dan bersosialisasi di dunia maya.

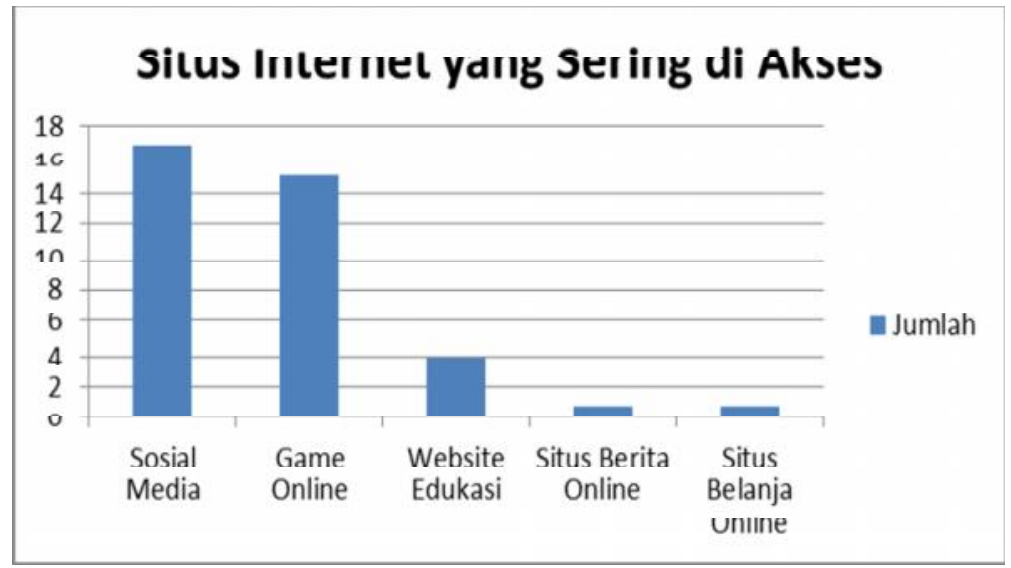

Gambar 5. Situs Internet yang Sering di Akses 
b. Apakah mengetahui potensi atau resiko anak menggunakan Internet

Berdasarkan hasil kuesioner dapat ditarik kesimpulan bahwa sebagian besar orang tua belum mengetahui dampak negatif dari penggunaan Internet. Sejumlah 15 responden mengetahui dampak negatif dari penggunaan Internet, dan 23 responden lainnya tidak mengetahui dampak negatif dari penggunaan Internet oleh anak.

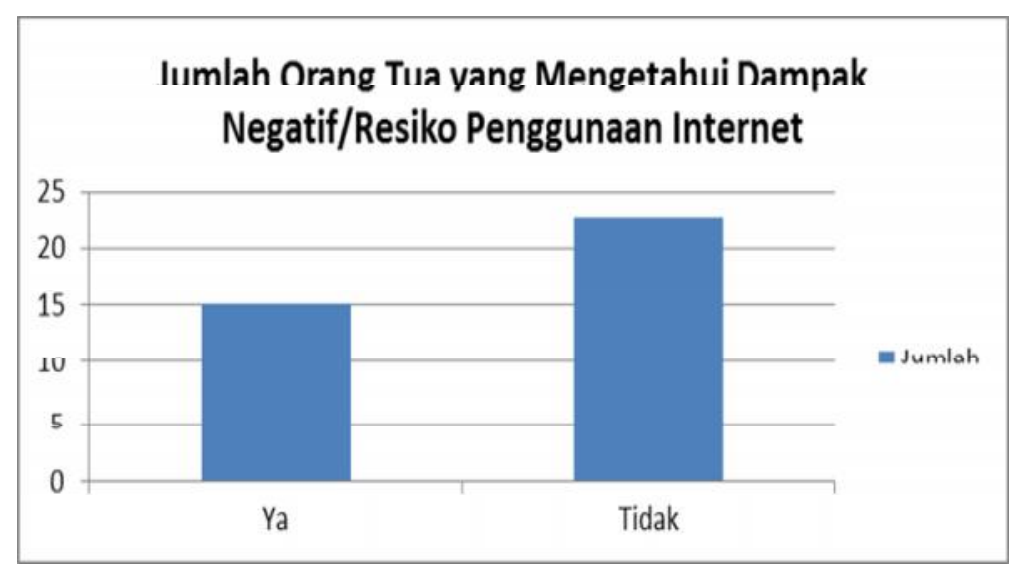

Gambar 6. Jumlah Orang Tua yang Megetahui Dampak Negatif/Resiko Penggunaan Internet

c. Apakah mengetahui tips menggunakan Internet dengan bijak?

Berdasarkan hasil kuesioner dapat ditarik kesimpulan bahwa sebagian besar orang tua belum mengetahui tips bijak menggunakan Internet. Sejumlah 8 responden mengetahui tips bijak penggunaan Internet, dan 30 responden lainnya tidak mengetahui tips bijak dalam penggunaan Internet.

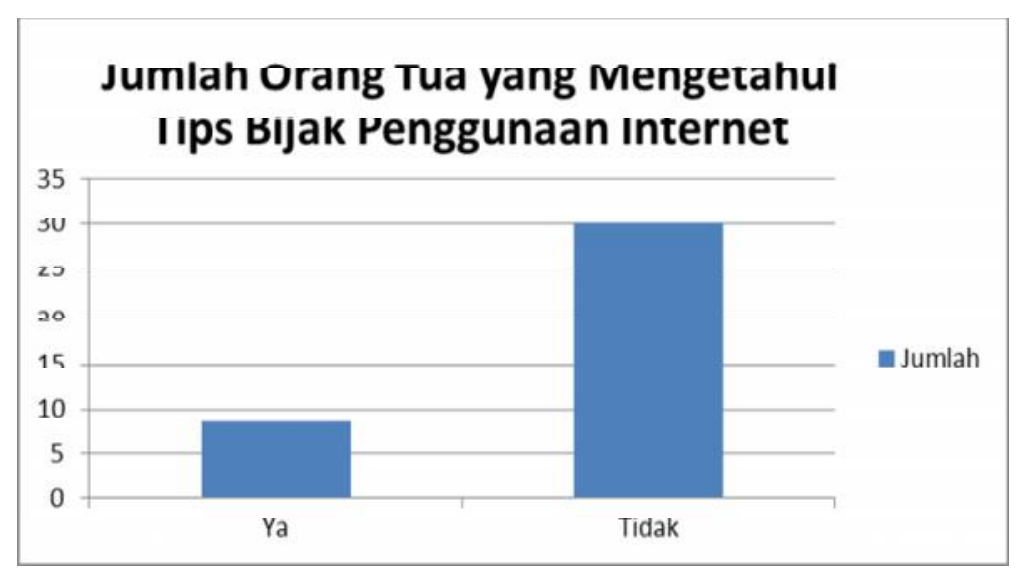

Gambar 7. Jumlah Orang Tua yang Mengetahui Tips Bijak Menggunakan Internet

d. Apakah mengetahui tata cara penggunaan fitur Parental Control pada smartphone sebagai langkah pencegahan penggunaan konten negatif di Internet?

Dari hasil kuesioner dapat diketahui bahwa sebesar 95\% dari peserta sosialisasi belum mengetahui tata cara penggunaan aplikasi Parental Control sebagai langkah pencegahan konten negatif di Internet. 


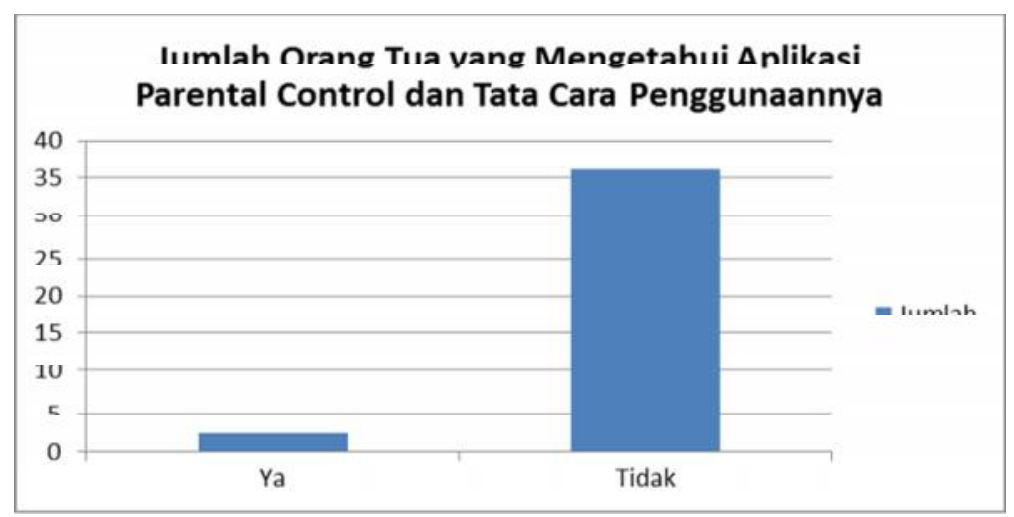

Gambar 8. Jumlah Orang Tua yang Mengetahui Aplikasi Parental Control dan Tata Cara Penggunaannya

\section{Materi Sosialisasi}

Sosialisasi e-safety parenting ini diikuti oleh 38 Ibu-Ibu PKK Dusun Trayeman, Bantul. Materi sosialisasi meliputi potensi atau resiko anak menggunakan Internet, tips menggunakan Internet dengan bijak pada anak serta mengetahui tata cara dan teknik untuk pencegahan konten negatif di Internet.Terdapat potensi resiko anak dalam menggunakan Internet diantara yaitu cyber bullying, penyebaran hoax, penipuan online, kecanduan game online. Potensi resiko anak dalam menggunakan Internet dapat dicegah dengan mengimplementasikan tips bijak penggunaan Internet dan penggunaan aplikasi Parental Control pada smartphone. Berikut ini beberapa tips bijak penggunaan Internet yang dapat diimplementasikan untuk mencegah terjadinya potensi atau resiko yang timbul dari penggunaan Internet:

1) Tetapkan waktu untuk berInternet, jam dan durasinya

2) Tetapkan situs website yang boleh diakses oleh anak

3) Dampingi anak ketika menggunakan Internet

4) Jadi bagian dari aktivitas online anak, cari tahu apa yang menarik minat mereka

5) Cek history browser secara kerkala

6) Tetapkan media sosial apa saja yang boleh digunakan anak dan ikuti aktivitasnya

7) Tetapkan game atau aplikasi yang boleh diunduh dan diinstal, kenali jenis rating game

8) Setting aplikasi Parental Control pada smartphone untuk memfilter konten yang akan diakses oleh anak

Tata cara penggunaan fitur Parental Control pada smartphone

1) Cari menu "Settings" di Play Store.

2) Kemudian "Parental Controls"

3) Geser tombol "On" ke posisi kanan 
4) Kemudian "Set content restrictions for this device" pilih sesuai umur yang diinginkan.

5) Buka pengaturan (setelan) $\rightarrow$ kontrol orang tua. Secara default off. Aktifkan.

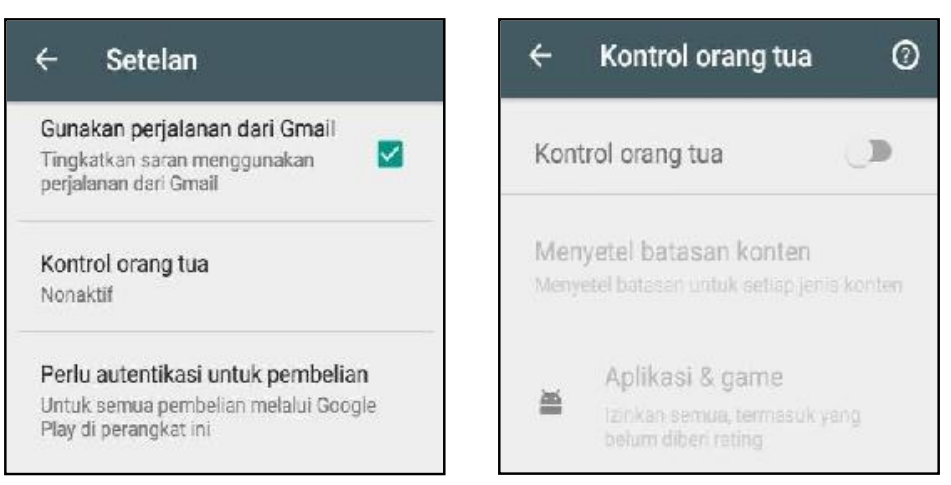

Gambar 9. Kotak Dialog Pengaturan Kontrol Orang Tua

6) Buat PIN 4 digit untuk mengaktifkan.

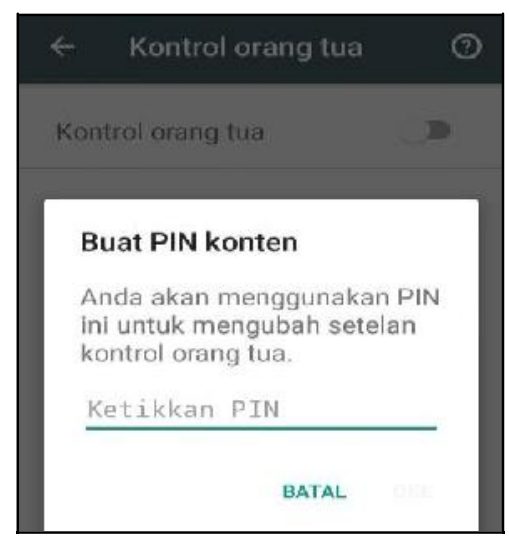

Gambar 10. Kotak Dialog PIN Konten

7) Normalnya semua aplikasi dan game akan tercentang. Terdapat 5 Rating + Semua diijinkan.
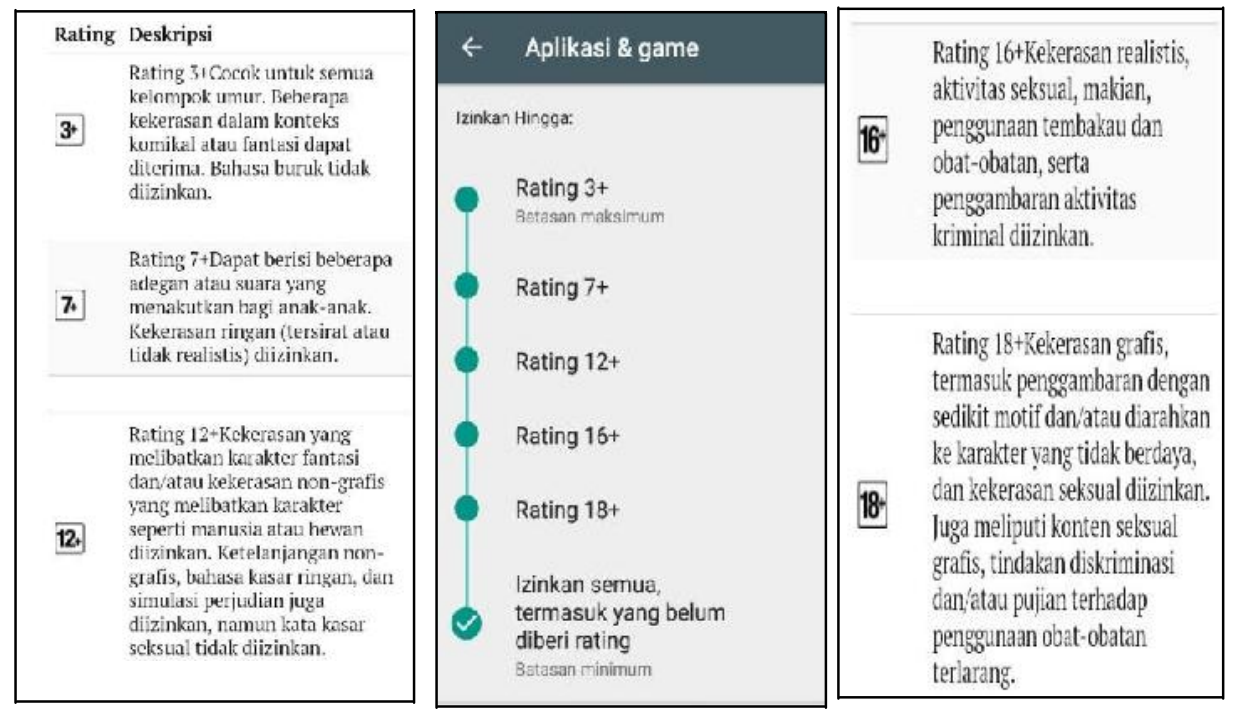

Gambar 11. Kotak Dialog Aplikasi \& Game dan Rating Deskripsi 


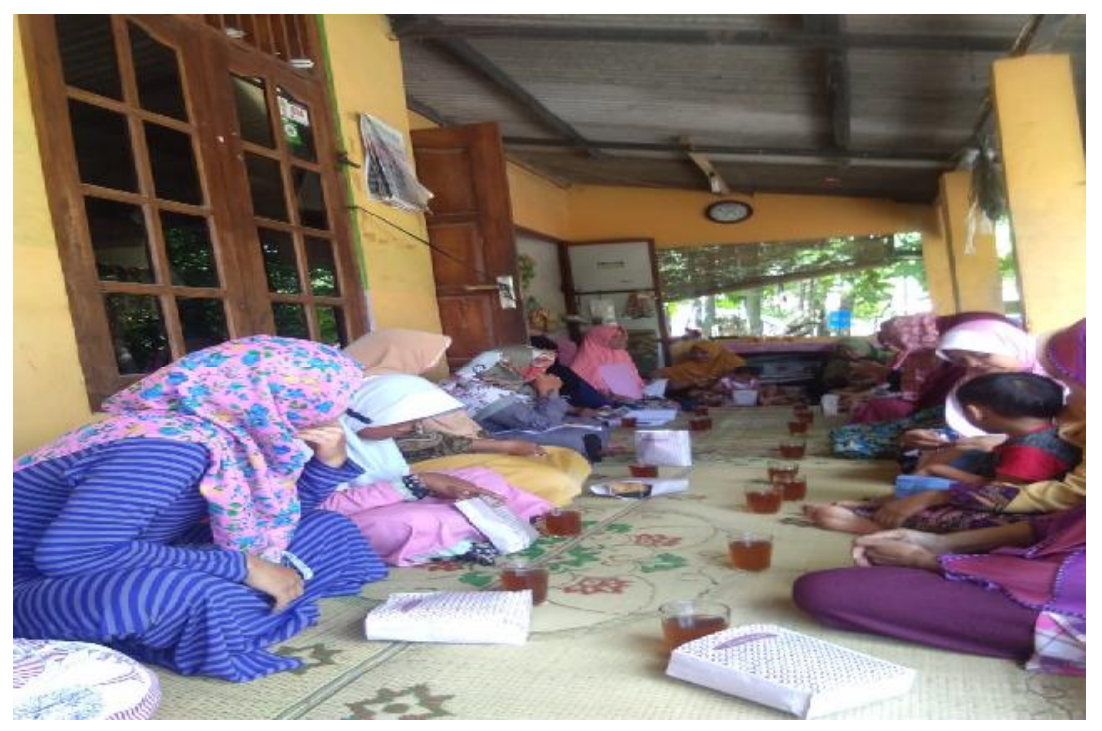

Gambar 12. Sosialisasi E-Safety Parenting pada Ibu-Ibu PKK Dusun Trayeman, Bantul

\section{SIMPULAN}

Pelaksanaan sosialisasi e-safety parenting mendapatkan respon yang baik dari Ibu-Ibu PKK Dusun Trayeman. Peserta sosialisasi antusias dalam mendengarkan ceramah dari narasumber. Hal ini dapat dilihat dari banyaknya pertanyaan yang diajukan terkait dengan pola pengasuhan anak di era digital dalam menggunakan smartphone khususnya penggunaan Internet. Setelah mengikuti sosialisasi ini, Ibu-Ibu PKK Dusun Trayeman sebagai peserta sosialisasi sudah memahami tentang potensi atau resiko anak menggunakan Internet, tips menggunakan Internet dengan bijak pada anak serta mengetahui tata cara dan teknik untuk pencegahan konten negatif di Internet. Peserta sosialisasi juga sudah bisa mempraktikan langkah-langkah menggunakan aplikasi App Secure Parental Control pada smartphone mereka. Diharapkan dengan mengikuti sosialisasi e-safety parenting, Ibu-Ibu PKK Dusun Trayeman dapat mengedukasi keluarga mereka tentang dampak negatif penggunaan gadget dan mengarahkan penggunaan gadget tersebut untuk kegiatan yang positif.

\section{DAFTAR RUJUKAN}

Asosiasi Pengguna Jasa Internet Indonesia (APJII). (2017). Penetrasi \& Perilaku Pengguna Internet Indonesia Tahun 2017.

Chusna, P. A. (2017). Pengaruh Media Gagdet Pada Perkembangan Karakter Anak. Dinamika Penelitian: Media Komunikasi Sosial Keagamaan. 
Fitri, S., Rubiani, H., \& Astuti, W. (2018). Sosialisasi Berinternet Sehat dan Aman Untuk Remaja. Jurnal Abdimas UMTAS.

Sholeh, M., \& Basuki, U. J. (2018). Implementasi Program Kuliah Kerja Nyata Melalui Sosialisasi Internet Sehat Bagi Remaja Masjid Aqrob Wojo. Jurnal Pengabdian Masyarakat: ADIMAS.

Wanto, A., Suhendro, D., \& Windarto, A. P. (2018). Pelatihan dan Bimbingan dalam Pemanfaatan Internet yang Baik dan Aman. E-DIMAS: Jurnal Pengabdian kepada Masyarakat. 